\title{
Development of Tie-Dye Technique on T-shirts in RT02 RW04 Sukawarna Village, Sukajadi District, Bandung
}

\author{
Lois Denissa $^{1 *}$ \\ ${ }^{1}$ Diploma of Art and Design, Faculty of Art and Design, \\ Maranatha Christian University, Bandung, Indonesia \\ lois.denissa@art.maranatha.edu \\ Rosa Permanasari ${ }^{2}$, Cherish Rosethalia ${ }^{3}$ Anjeli Tania $^{4}$, Vania Hindriana, $\mathrm{Ngo}^{5}$, \\ Felicia Gunawan ${ }^{6}$, Gerardine Nathania $^{7}$, Devina Theodora ${ }^{8}$, Clemensy Aurelia ${ }^{9}$ \\ 2,3,4,5,6,7,8,9 Diploma of Art and Design, Faculty of Art and Design, \\ Maranatha Christian University, Bandung, Indonesia \\ rosapermanasari@yahoo.com, 1861005@art.maranatha.edu, 1861007@art.maranatha.edu, \\ 1861012@art.maranatha.edu,1861004@art.maranatha.edu,18610010@art.maranatha.edu, \\ 1861014@art.maranatha.edu, 1861022@art.maranatha.edu
}

(Received October 22, 2021, accepted February 08, 2022)

\begin{abstract}
Creativity is an essential thing that everyone needs to have so that life continues to be filled with constructive progress. The development of tie-dye technique is one of interesting textile design creativity because it is a synergistic experiment between technique and color. The application of the tie-dye technique on T-shirts as a form of community empowerment activity is considered to have power to stimulate ideas for developing the creativity of Islamic boarding school students in Sukawarna Village. The combination of various techniques such as tying, folding, sewing, wrinkling, and dyeing creates a natural and expressive movement of absorbent color that occurs permanently on the fabric. The participatory demonstration method which is directly applied to media by the participants with lecturers and students' assistance becomes an effective method in producing interesting works. Participants have a rich visual repertoire of unexpected shapes and colors that can occur in fabrics while watching their friends explore. The conclusion of this creative experience becomes a force for students to be enthusiastic about continuing to work, until one day they have an opportunity to be self-sufficient. This unique result, if managed properly, will bring in consumers so that it can boost the family and even regional economy.
\end{abstract}

Keywords: creativity development; self-sufficiency opportunity; tie-dye 


\section{Introduction}

In recent decades creativity has received increasing attention, creativity is considered as a valuable asset to open up ideas and possibilities that benefit him as well as for others. Society will gain social, aesthetic and technical improvements in the improvement of quality of life and culture from creativity. Recent surveys state that creativity is the most sought-after top ranking characteristic. In IBM's survey of 1541 CEOs in thirty-three major industries and sixty countries in the world (Berman, 2010) gained creativity as a series of key abilities to reach the peak of the future. Adobe's survey of 2,000 teachers and 2,000 parents in Germany, the UK, Australia and the US (Adobe, 2013) said creativity was the most preferred educational goal as a 21st century skill, in addition to communication, collaboration and critically thinking. Creativity (Munandar, 2004) is a creative product that is born from the uniqueness of individuals when interacting with their environment. There is an internal motivation to produce something unique while working condition.

This valuable condition needs to be given encouragement and opportunities in the form of activities as a stimulus in order to create valuable creative products. The tendency to hone creativity can be done by learners or anyone else, through various active activities such as drawing, singing, making products of various forms. The form of the product also varies from processed works that are 3-dimensional, 2-dimensional, giving ornamental variety, texture to coloring techniques. Each participant can realize his or her impulse in processing works of appearance and sound work freely, the results of their own creations that can be made. The creative urge to be free without fear of being ugly or afraid of being wrong, daring to try something different from what is commonly encountered is a characteristic of creativity that can develop. The desire is always there to continue to explore relentlessly and be able to make judgments on its new findings, whatever the outcome.

Creativity will find new ideas and ways to produce unequal things, which are not similar, somewhat different slightly or differently to the usual, or strange even though allowed, in the name of creativity. Creativity is the basic thing that everyone needs to have and something that can be trained and developed in order to find new things that change lives more meaningful and more useful in the future. 
The development of this tie-dye technique on T-shirts using pure cotton dye media, namely Dylon with warm water diluent, has proven to be ideal for producing interesting tie-dye works. In developing the tie-dye technique on T-shirts, participants were introduced to self-expression that encouraged personal creativity. Starting from binding techniques, auxiliary media for bonding, various forms and directions of stitches, wrinkles, various folds and pressures, the use of 2 coloring techniques, namely pouring and dyeing techniques, color selection can be explored further so as to produce creativity that can continue to be explored.

The finished T-shirt fabric is then hung and dried in a bonded state until it is half dry. A texture will appear from the combination of bonding, folds, pressure, stitching, and coloring, which are unexpected and even surprising when the rope/rubber ties are opened. This training activity is rich in creative activities, namely the merging of the right brain and left brain which is needed for the development of life in the present and in the future.

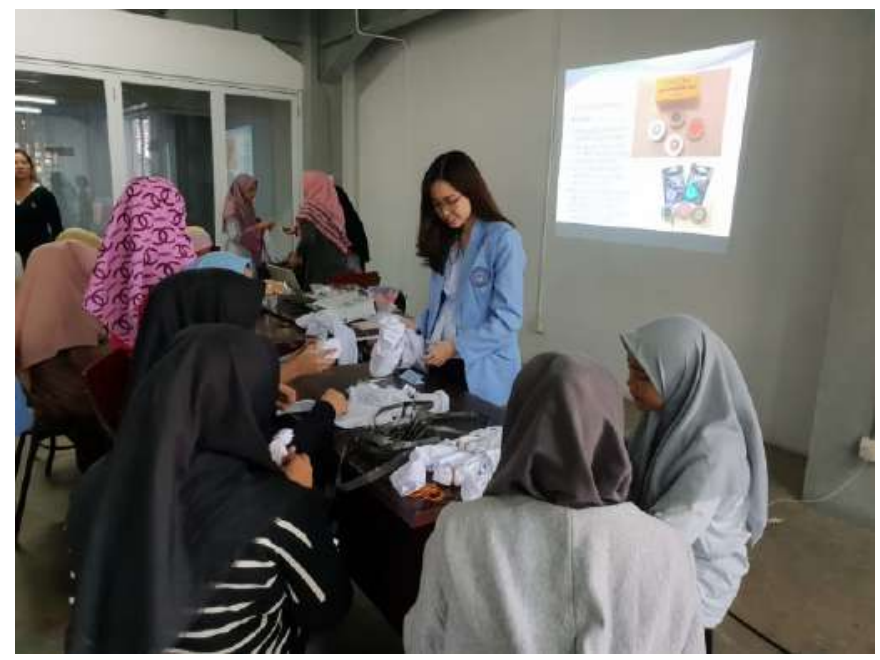

(source: documentation of diploma III fashion design study program)

Fig. 1. Participatory demonstration method by student

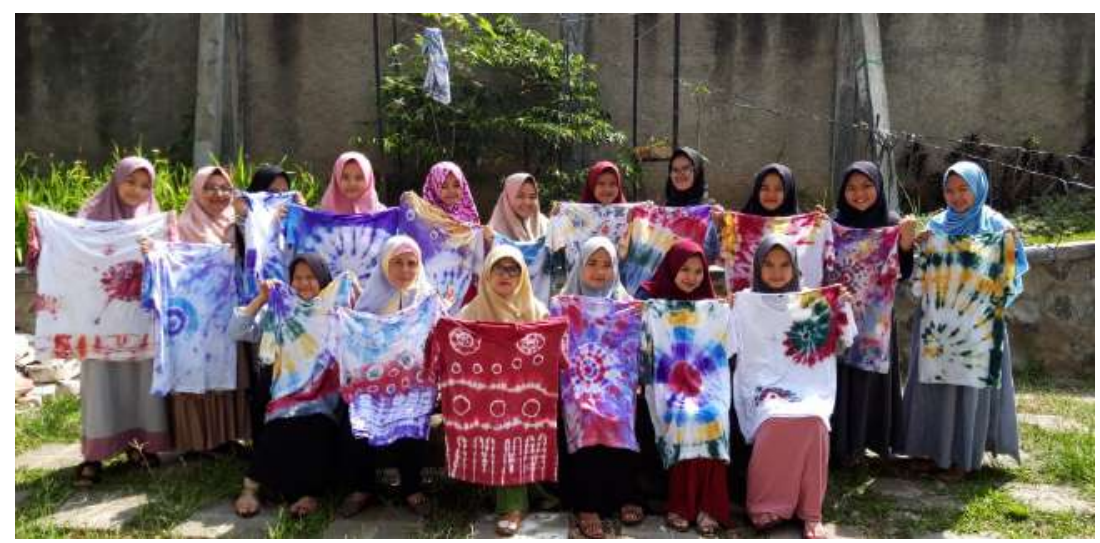

(source: documentation of diploma III fashion design study program)

Fig. 2. Attractive and personal tie-dye pattern 
This tie-dye technique activity is personal in nature, able to stimulate the creativity of participants to create various interesting and unique visual possibilities according to their respective aesthetic impulses. The choice of colors, the development of techniques on how to prevent color from seeping into the fibers of fabric will have consequences for the final result of tie-dye produced variety. In this case, practice becomes a valuable experience. Furthermore, this community empowerment activity requires evaluation in order to obtain constructive input for future art and design activities.

The picture below describes several forms of T-shirts found in the market that the tie-dye method can not only be applied to T-shirt material but can also be applied to shirts, work clothes, kebaya and children's clothing as well. This is intended to illustrate that the tie-dye method is not only very interesting and challenging for creativity but can also be developed in many types of clothing and products. The large field of application development for clothing and tie-dye application products opens up opportunities that are of commodity value.

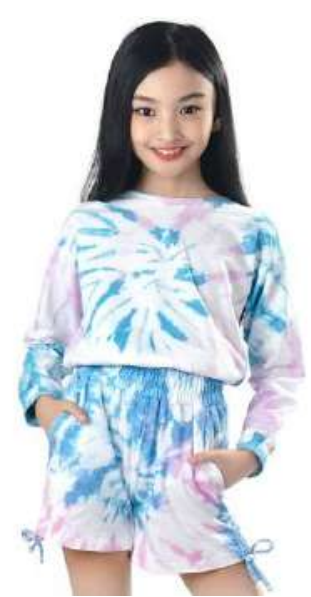

(source: https://www.zalora.co.id/kids-icon-kids-icon-jaket-tie-dye-anak-perempuan-curly-04-14-tahun-withrib-detail-ly400100210-blue-2782125.html)

Fig. 3. Tie-dye children's clothes in Zalora advertisement

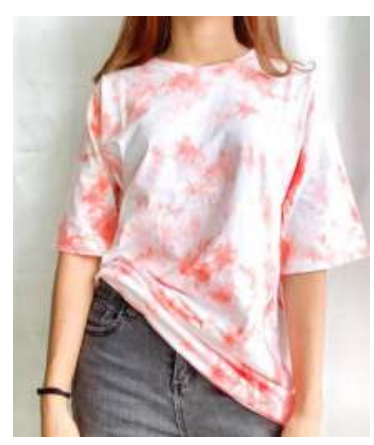

(source: https://shopee.co.id/Baju-tie-dye-lengan-pendek-murah-unisex-kualitas-bagus-kaos-tie-dye-murahunisex-baju-tie-dye-i.273203728.4637551506)

Fig. 4. Tie-dye T-shirt on Shopee advertisement 


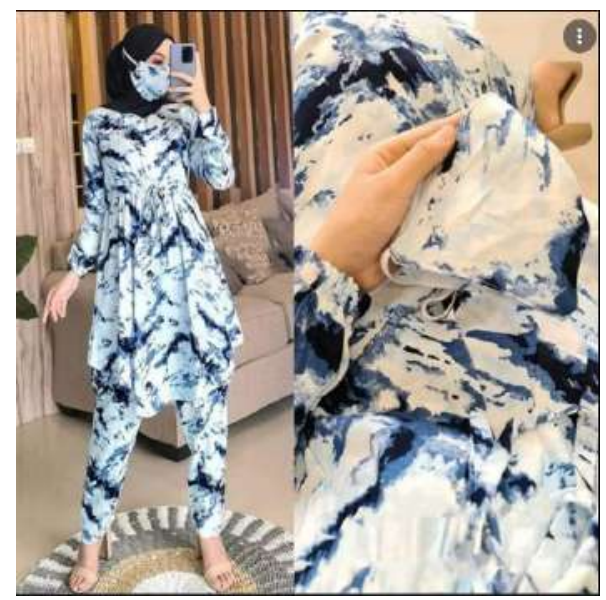

(source: https://www.lazada.co.id/products/glason-set-daily-set-rayon-setelan-gamis-terbaru-2020-baju-tidurmodel-terbaru-baju-tidur-setelan-dewasa-daily-set-hits-piyama-wanita-dewasa-i3082274828.html)

Fig.5. Tie-dye robe on Lazada advertisement

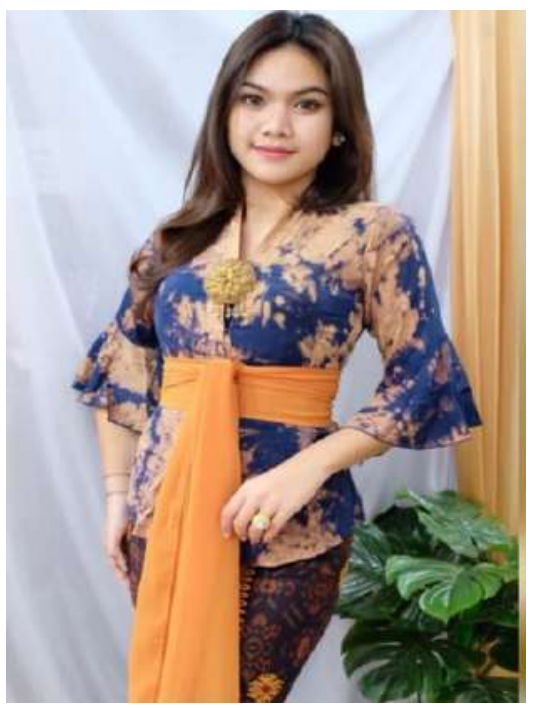

(source: https://shopee.co.id/Kebaya-Tie-Dye-i.127601574.5241097489)

Fig. 6. Tie-dye kebaya on Shopee advertisement

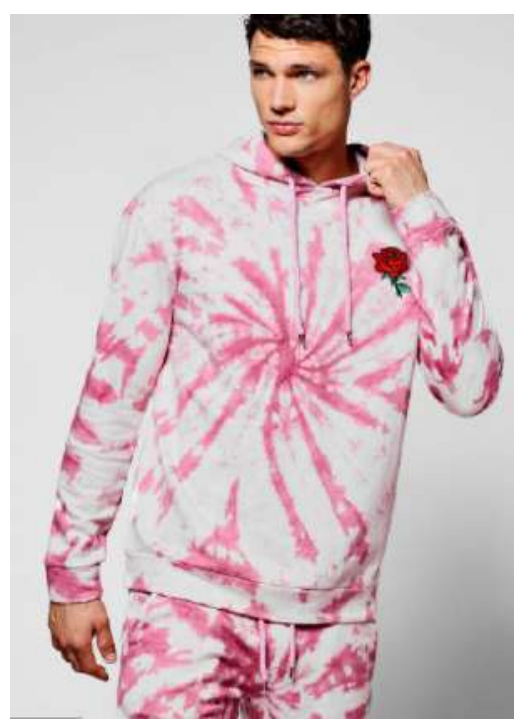

(source: https://nz.boohoo.com/oversized-tie-dye-hoodie-with-rose-embroidery/MZZ71702.html)

Fig. 7. Coat tie-dye in a Boohoo advertisement 
The tie-dye technique development activity on T-shirts was carried out well, on June 22, 2019, in the Textile Workshop room of Diploma III Fashion Design Study Program, Maranatha Christian University. The activity was attended by 26 participants, the boy and girl students and women of the Islamic boarding school were guided by Mrs. Siti Oliah as secretary of RW 04, Sukawarna Village, Sukajadi District, Bandung.

\section{Methods}

The development of this tie-dye creation training uses the participatory method of participants in the practice of applying tie-dye on a T-shirt by following the module that is shown in the lecturer's presentation (Majidah, 2021). The next training was carried out demonstratively by lecturers and students from Maranatha, then participants followed the steps that were taught directly. Things that were not understood during the exercise could be asked directly, so here participants got direct assistance from lecturers and students from binding techniques, color selection and dyeing, drying, checking the creations to evaluating the consequences of the tiedye process that has been carried out by participant. The various binding techniques that have been described in the presentation form the basis of a guide which the participants could then explore according to their respective creativity. Participants got directions on the chosen binding technique by imagining the structure of the shape obtained when the tie-dye process has been completed. Although the structure of the shape has been determined with the same binding technique, however, the result of tie-dye is never the same, even if it is done by the same person and in the same way. The tightness of the bond, the binding material, the number of bonds, the shift of the bond, the choice of color, the time of dyeing and drying, make the tiedye results are surprising, unique and the end is never the same. The results are always distinctive cause attraction, a sense of awe, and trigger feelings of happiness (Widodo, 2012).

1. Tutorial

Provision training materials were carried out with a short presentation by a Fashion Design lecturer covering the background, time, and place of the history of tie-dye. The term tie-dye, the Javanese people call it Jumputan, the Palembang community call it Rainbow cloth, the Kalimantan people call it Sasirangan, and the Sulawesi people know it as Rotto cloth. Jumputan is understood as a technique of making motifs on textiles by tying, folding the fabric with techniques that are constantly being developed. Efforts to hinder the seepage of dyes when the fabric is dyed/poured with dyes. The selection of appropriate material for training is a pure white cotton T-shirt because it will be colored. The coloring used a dyeing 
or pouring technique on a T-shirt that had already been treated with binding, sewing, wrinkle, folding or clipping, depending on the tastes and creations of the participants. This possibility was preceded by tutorials from lecturers and lecturers' assistants together with students at the time of implementation. Participants got directions, knowledge, manufacturing modules, hands-on practicals with step-by-step supervision to produce their own tie-dye technique T-shirts.

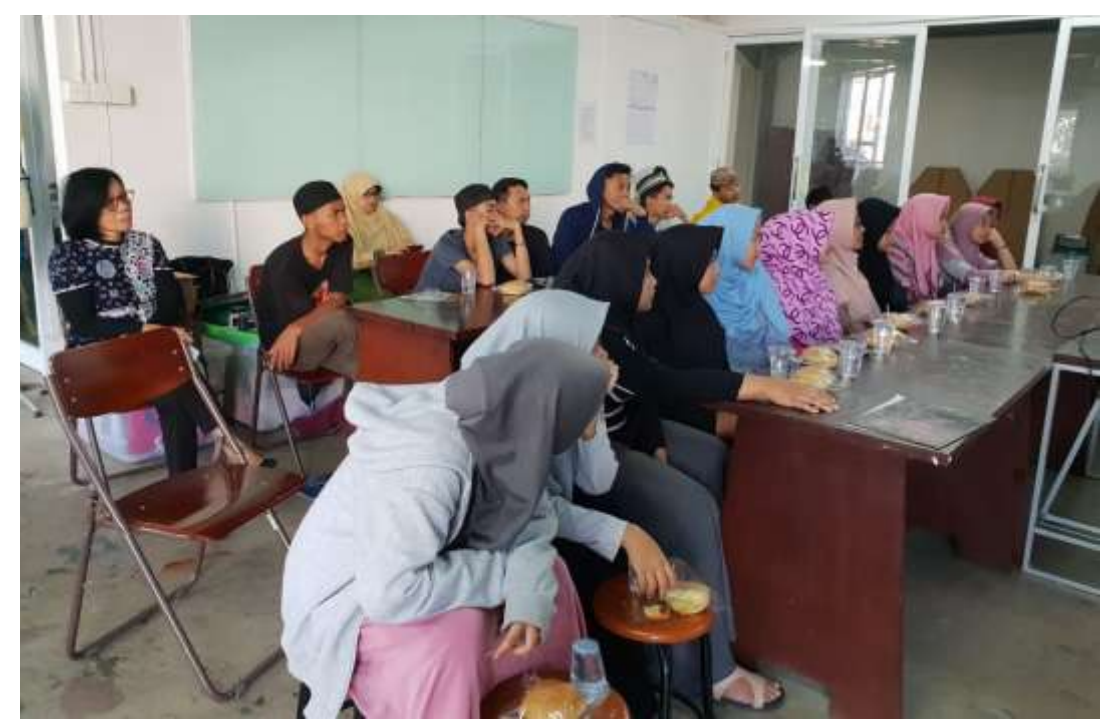

(source: documentation of diploma III fashion design study program)

Fig. 8. Listening to tutorial presentation

2. Studying the Module

The provision of modules was given as a guiding medium for the service participants to make it easier to understand the process of making various creations of ties, folds, twists, stitches and media that can be inserted into ties. The module provided has three different types of cutting and sewing techniques. Table 1 and Table 2 are a visual illustration of one of the modules implemented in this activity.

\section{Participatory Demonstration}

Participants received direct instructions on the types of tie-dye techniques. This technique is an example that can be followed by the tie-dye results that can be achieved when applied to a T-shirt. Subsequent training was carried out through mentoring demonstrations on how various techniques of tying, folding, clamping, wrinkling, sewing were applied to the parts of the T-shirt. Participants could choose and explore the desired technique themselves by asking directly to the lecturer and students. On this occasion, participants had the opportunity to bring used plain color clothes that had faded to be updated in color and pattern 
with the tie-dye technique to become clothes with a new look. This participatory demonstration tutorial method becomes effective as participants can imagine what result will be when the tie-dye process is opened. How the color is chosen is also a determining element, whether the technical dyeing is done at once, 1 color, 2 colors, various colors in parts or color pouring techniques. The various steps of the bonding technique and the coloring technique open up a range of possibilities for very rich and unique results, one with the other.

Table 1. Tie-dye technique type module
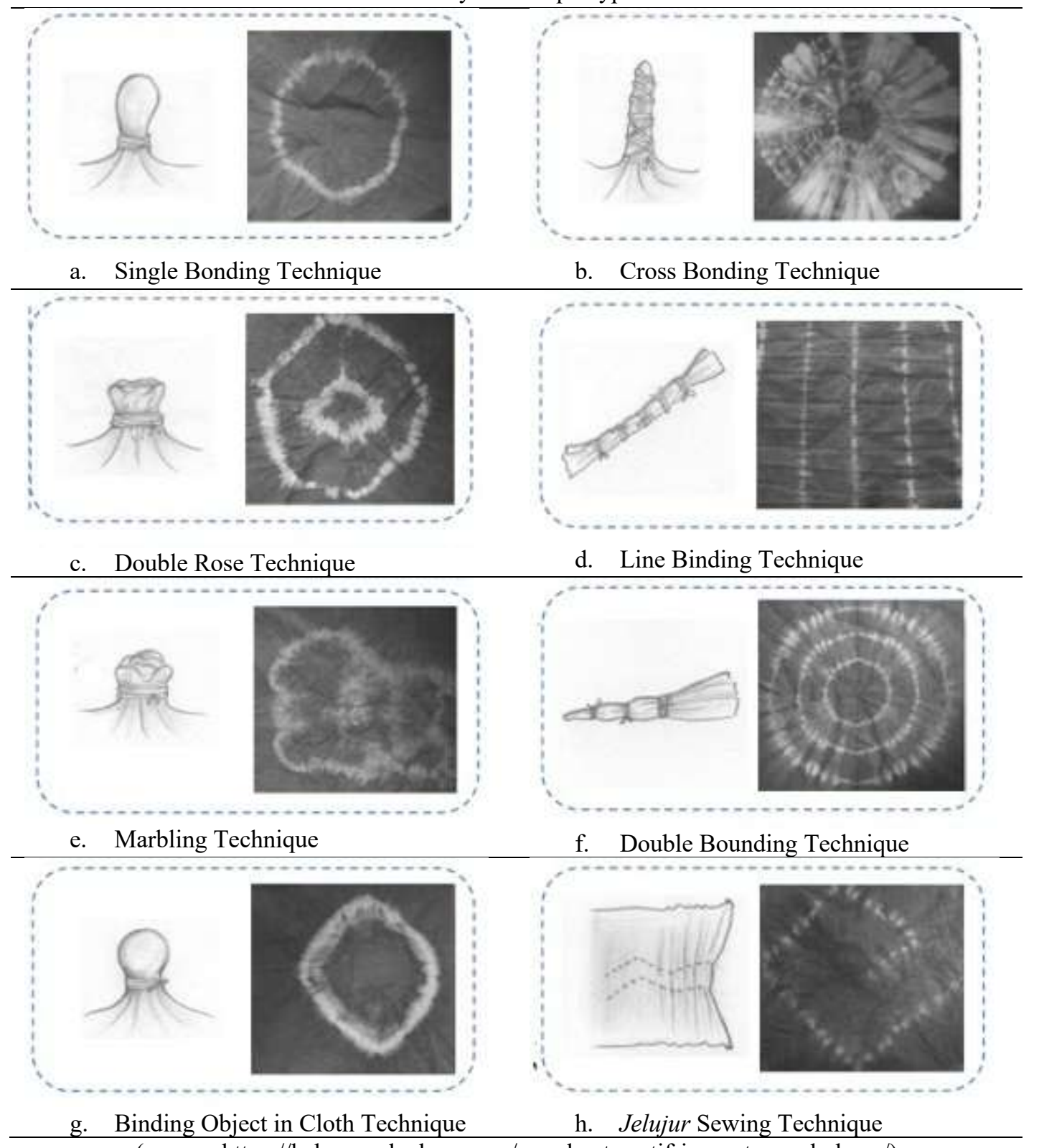

(source: https://kabarpandeglang.com/membuat-motif-jumputan-sederhana/) 
Table 2. Examples of tie-dye results
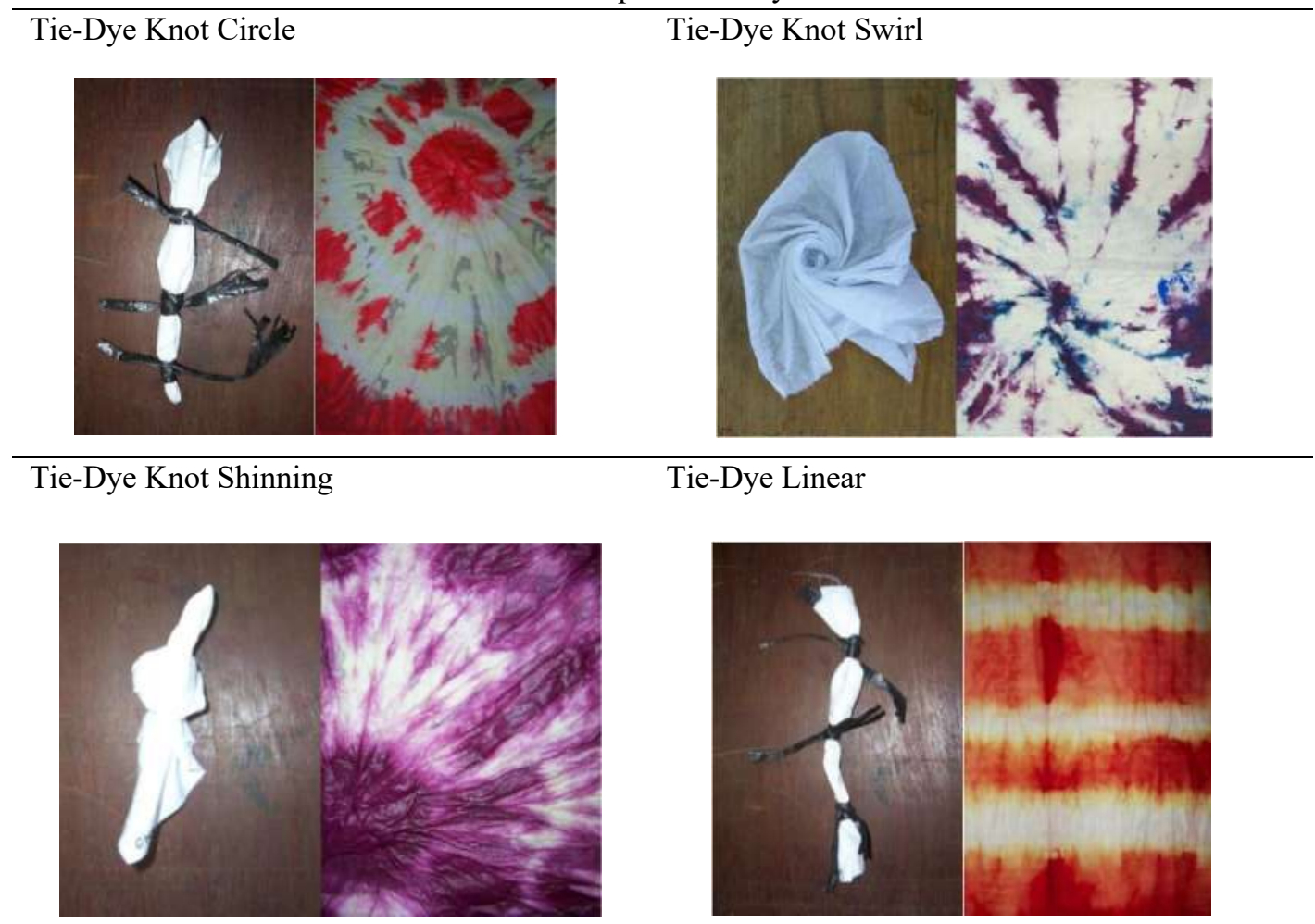

Tie-Dye Linear
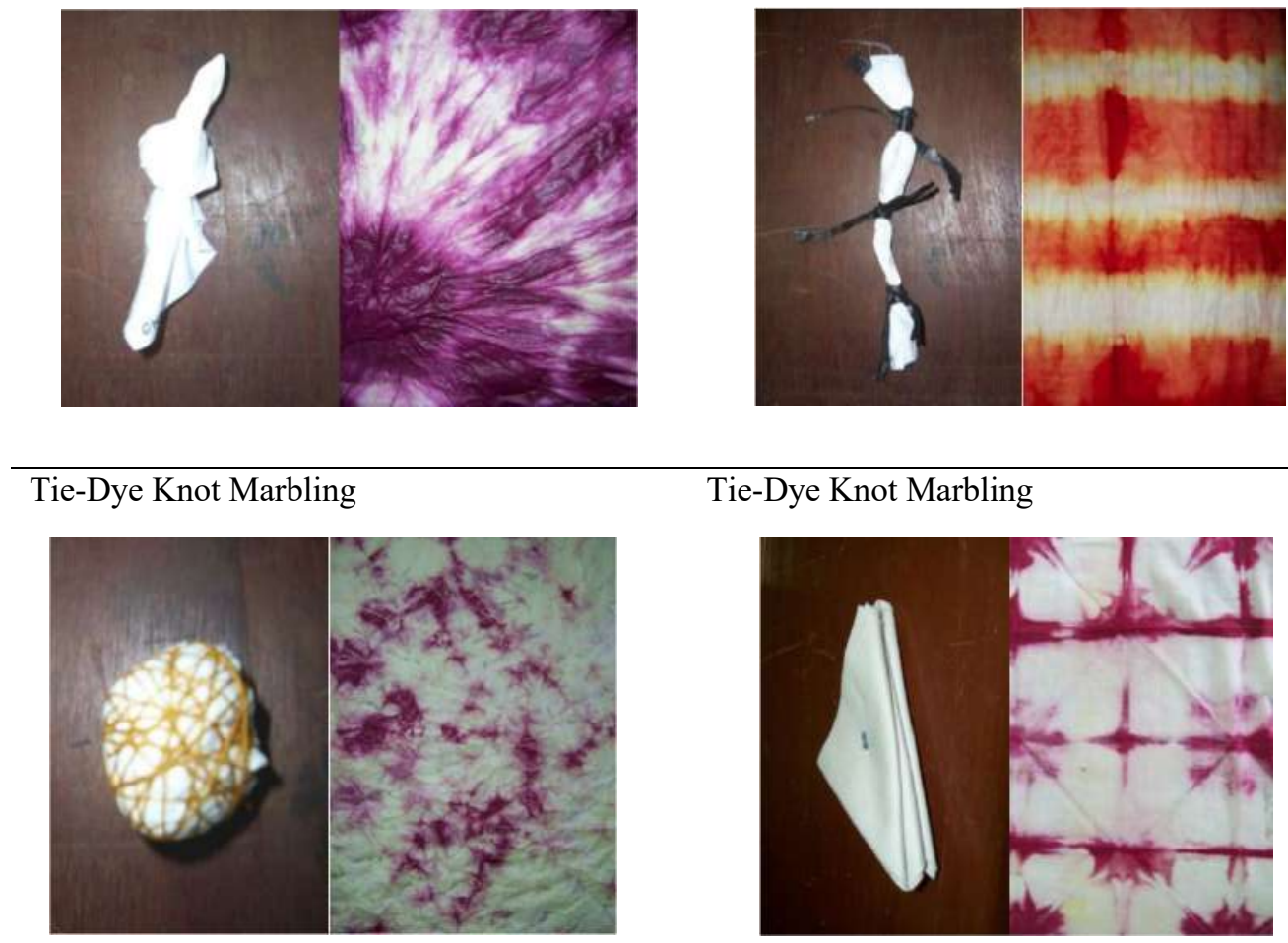

Tie-Dye Knot Marbling

(source: https://kabarpandeglang.com/membuat-motif-jumputan-sederhana/)

\section{Results and Discussions}

The presence of Diploma III Fashion Design Study Program is recognized by most of the community in RT 02 RW 04, Sukawarna Village, Sukajadi District, which is located right behind Maranatha campus site. They began to know and be familiar with Diploma III Fashion Design Study Program after an initial community empowerment activity was carried out a few years ago. This service activity is the second activity carried out by the Study Program which is enthusiastically welcomed and accepted by most of the participants. Some of the participants, both pesantren youths and local women, were participants who had attended past training, but there were also some who attended for the first time. There is a sense of closeness between the 
implementers and the participants because they have known each other so that the ties friendship between the implementers and the trainees are getting stronger. All participants of the activity showed joy in getting additional valuable new.

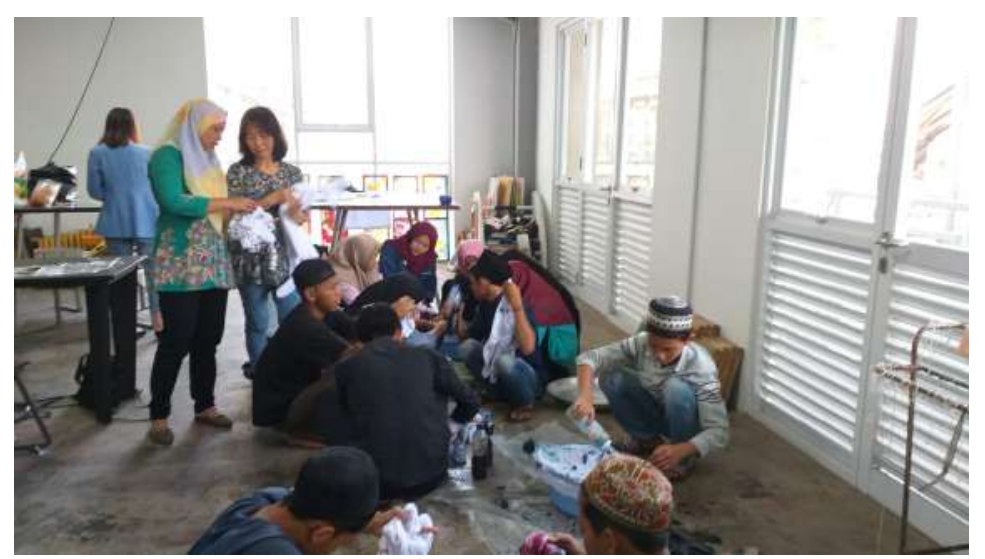

Source: documentation of diploma III fashion design study program

Fig. 9. Participatory demonstration method by lecturer

Activities that involve participation of students have a positive impact, students have opportunity to practice the knowledge and skills acquired directly. Lecturers and students are able to work together in service activities and able to socialize more closely with the community around campus. This activity has a positive impact on both parties, there is a transfer of knowledge and skills that are useful in increasing the intelligence of surrounding community. On the other hand the presence of Diploma-III Fashion Design study program is recognized and well received by the community. This condition creates an environmental feel that supports the safety and comfort of Maranatha Christian University students who live in boarding houses around Maranatha campus. The existence of campus with all its activities has full support from the surrounding community because of the mutual benefits that can be received by both parties.

Understanding this potential, Mr. Ahmad, as chairman of RT 04 Sukawarna Village which is located right behind the Maranatha Christian University campus, invited the Diploma IIIFashion Design Study Program to further enhance the experience of textile design for all residents who are interested in learning and improving their fashion design skills. This activity is open to all students, both youths, women, fathers and mothers, whose numbers are dozens of umpi/families. The study program is not able to accommodate all the wishes of residents who are interested in learning due to limited workshop space. So this training is intended for 
residents who are really interested and committed to participating in the entire training to completion.

Citizens who do not have a genuine interest will not be able to complete the exercises properly. Participants must follow the entire process of making textile designs with the tie-dye method which is applied directly to plain T-shirts. Guidance was given since the distribution of the tiedye motif design layout, continued with the selection of bonding or folding techniques or a combination of them, color selection and coloring techniques, drying to opening the color absorption barrier bonds used. The invitation was responded by Diploma-III Study Program positively and internally. The Diploma-III Study Program makes this activity a form of community service which is carried out as a lecturer activity together with students.

Furthermore, if this third service activity gets a positive response from local residents, then it becomes a sustainable need, then this citizen's request can be followed up and developed into a programmed routine coaching activity. The chairman of the implementation of this community empowerment activity is chaired by Dr. Ir. Lois Denissa, M.Sn, then realized this activity by conducting a survey first. The head of the service held talks with the head of local RT, initial briefing to participants, making activity proposals to procuring funds from the Research and Community Service Institute to obtain an agreement to be realized. Procurement of this activity must obtain approval of head RT as well as secretary RW in order to obtain a mutually beneficial form of cooperation.

A few weeks before the activity, the implementing lecturer discussed with the students in advance to provide an explanation of the activity material and coordinate the division of tasks in order to obtain a synergistic cooperation stage during implementation. Lecturers together with students shop for activity materials together so that there is a sense of closeness to one another, not limited to relationships when they are in class. This togetherness is important so that lecturers can be role models for students when they practice being instructors in front of the community, there is a sense of closeness when transfer skills would run naturally and comfortably. Participants get a real visual picture before starting the training through a presentation by the chief executive. Towards the day of implementation, lecturer and students prepared equipment in the workshop in the form of: making additional applicators (making a cone shape on the cap of mineral water bottles other than the ones already purchased). Naming participants on T-shirts according to size, making attendance lists, preparing the necessary 
equipment such as pot readiness, stove, large bucket, stirrer, water scoop, oven mitt, lighter, soap, plastic mat for work, dipper, napkin and apron.

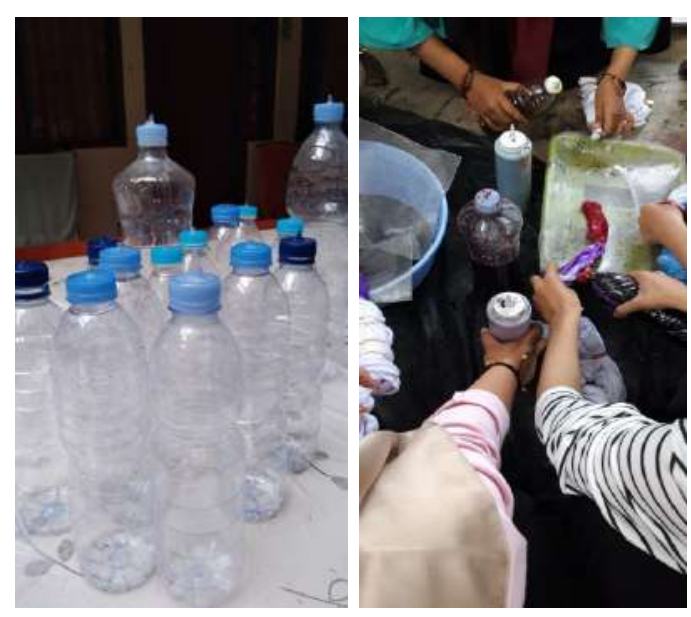

Source: documentation of diploma III fashion design study program Fig. 10. Applicator added

On the appointed day, participants gathered on the front porch of building B, at 08.00-08.30, at Maranatha Christian University campus. Participants were given instructions/delivered by security guards or students wearing university jackets to be recognized to the Textile Workshop room for a welcome event and got a presentation on the sequence of training activities carried out by the Head of Service.

During the presentation, member lecturers and students prepared hot water for solvent media for T-shirt dyes, divide hot water into 6 large buckets according to the number of colors that had been prepared. Dylon dye was dissolved in each bucket then added 1-2 tablespoons of table salt to strengthen the intensity of color when absorbed by T-shirt. In general, the intensity of the color will decrease after being absorbed by the fabric, so it is necessary to add table salt/NaCO3 to keep the color brighter. Some color solution from the large bucket was transferred to the applicator to make it easier to pour for practical application for color pouring technique. The remaining color left in the bucket was used for dyeing practice. 


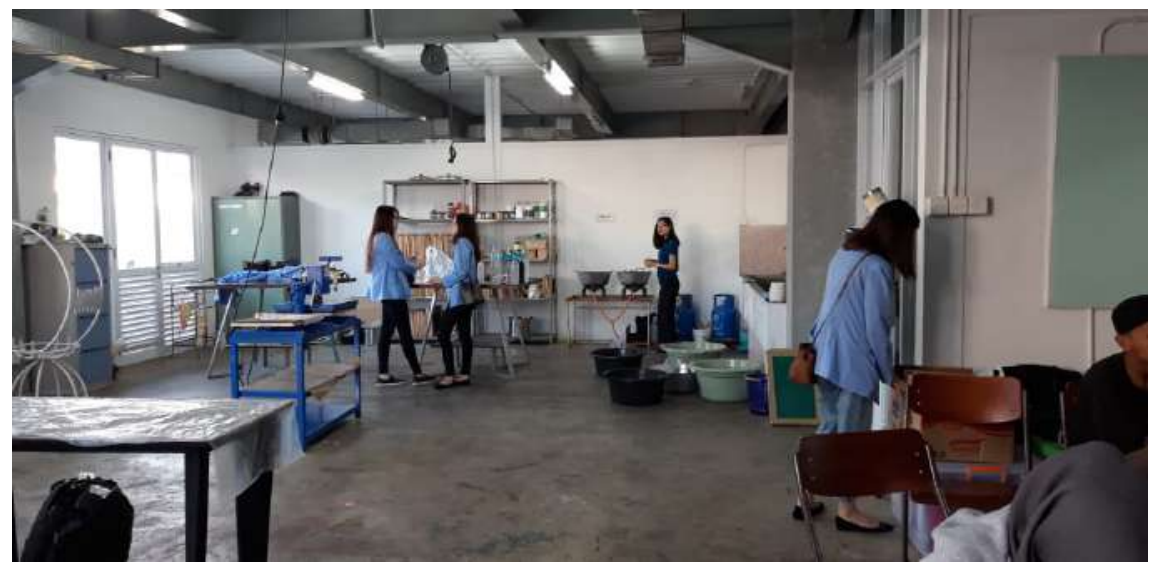

(source: documentation of diploma III fashion design study program)

Fig. 11. Preparation for making dye solution

At the coloring stage, participants were given freedom for chosing their desired color variation, folding or binding technique. The results they choose will always seem natural and unique, even though design of their ties or folds or emphasis or color of their choice will never be the same. This is creativity and unexpected surprise when the knot or fold is opened. The variety of motifs that arise and their exploration becomes a unique patterned fabric, characterizing the identity of the maker, unexpected and very interesting. Participants got a break at 12.00-13.00 for lunch while waiting for better drying before doing documentation and evaluating activities until those were finished.

All activities were fully guided by two lecturers as instructors with 7 students. Each student was given the responsibility to assist and train 4 participants to ensure that the activities run well and achieve their goals. This means that the training was carried out in a relaxed but serious manner so that each participant was able to complete the tie-dye creativity on their respective $\mathrm{T}$-shirts and second-hand clothes that they bring from their homes to obtain optimal results..Participants could go home with their own T-shirts with a sense of pride and satisfaction with their own work.

This activity ended at around 14.00 Western Indonesia Time and closed with a group photo event, filling out questionnaires by participants and then the implementing lecturers and students expressed their gratitude for the participants' willingness to take part in the training. Apologies were conveyed if there were things that were not pleasing, for the limitations in delivery and training facilities that had been carried out. Some of the participating mothers expressed their desire for more frequent, and more varied training in the future. This shows the 
enthusiasm of the participants to gain additional creativity and knowledge in the field of fashion.

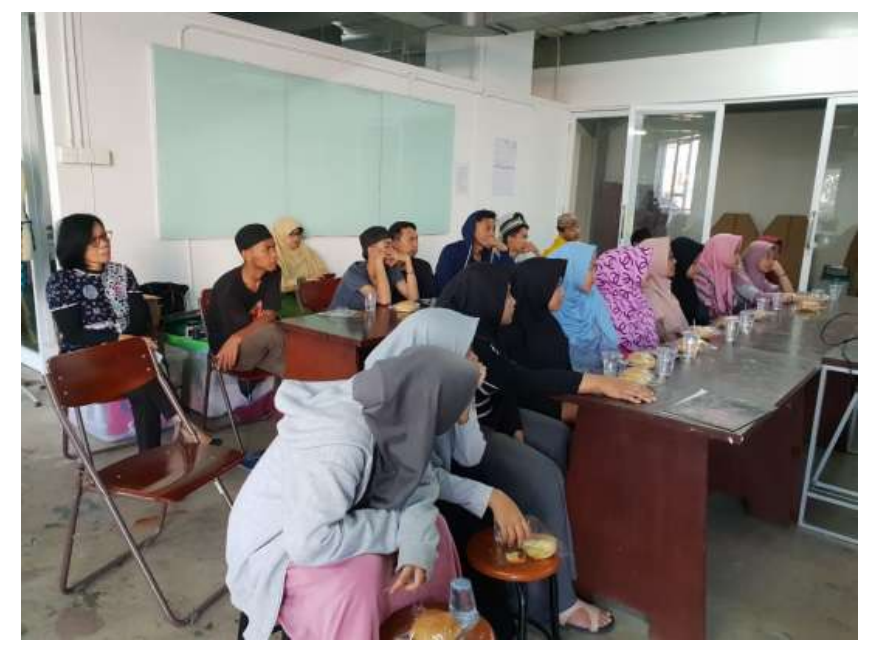

(source: documentation of diploma III fashion design study program)

Fig. 12. The atmosphere of participants listening to the presentation

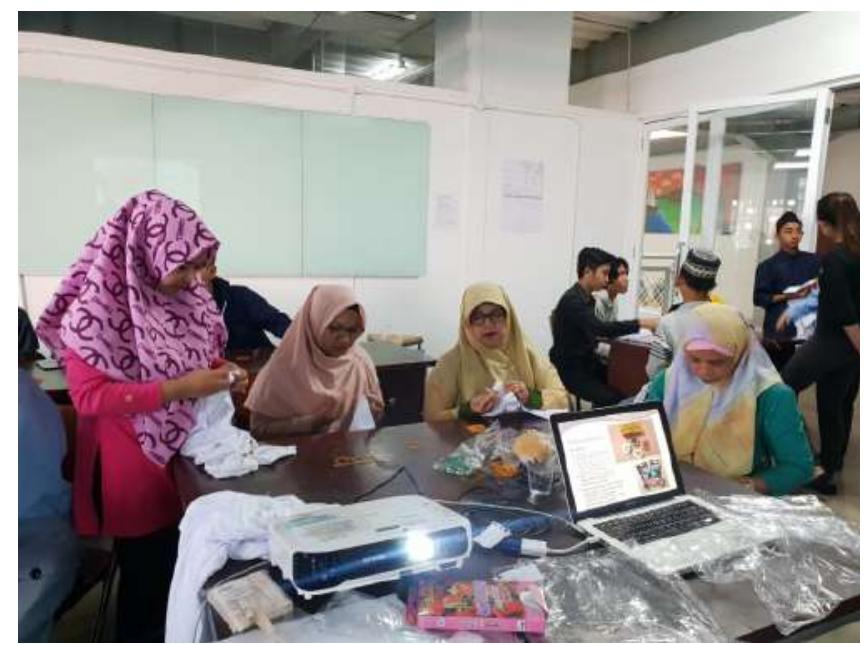

(source: documentation of diploma III fashion design study program) Fig. 13. Folding technique

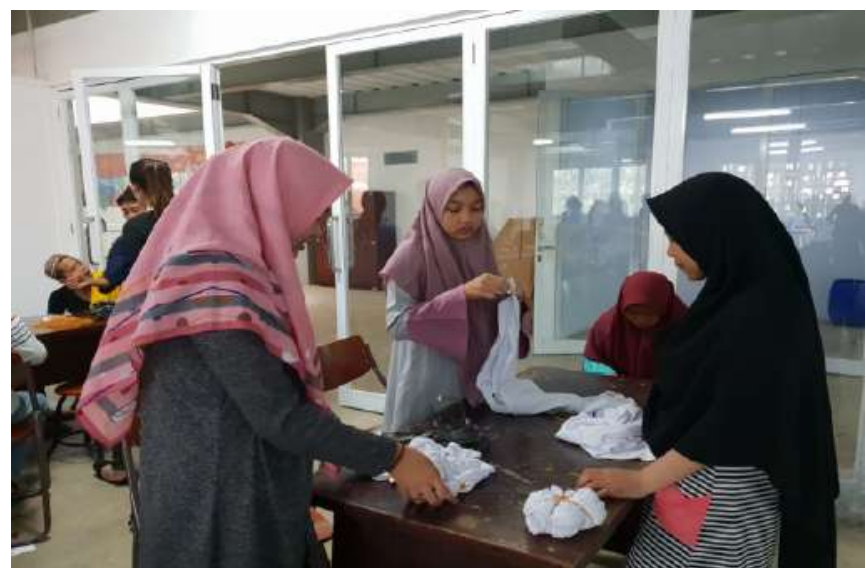

(source: documentation of diploma III fashion design study program)

Fig. 14. Tying technique 


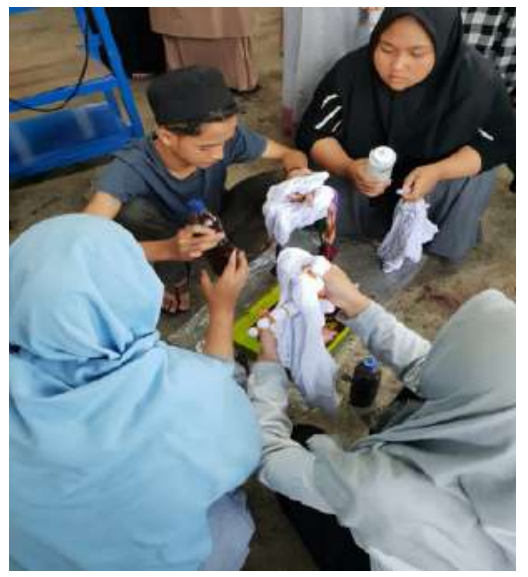

(source: documentation of diploma III fashion design study program) Fig. 15. Marble filling technique

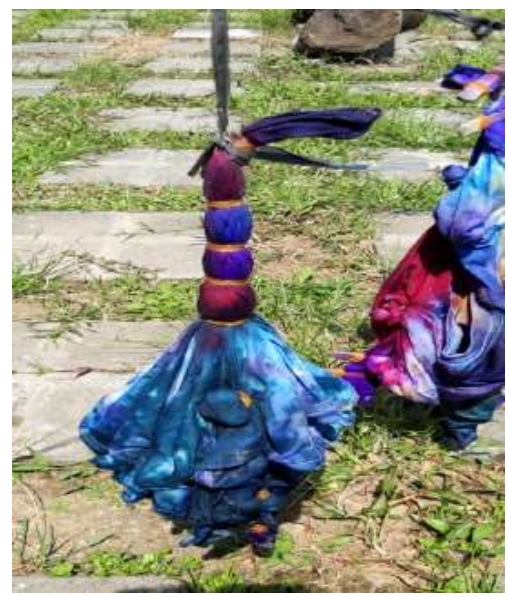

(source: documentation of diploma III fashion design study program) Fig. 16. Drying figure

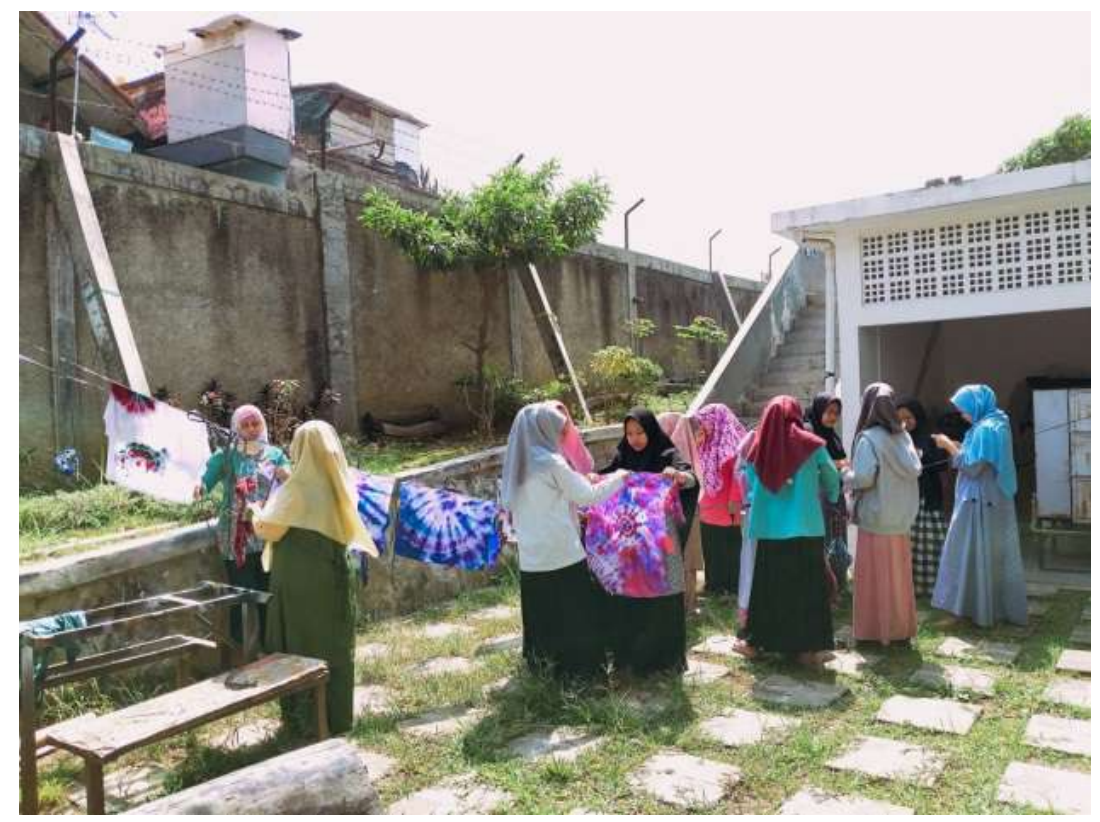

(source: documentation of diploma III fashion design study program) Fig. 17. Bonding, folding, and final drying 
The use of tie-dye on used clothes such as shirts or sweaters that have faded in color or slightly dirty is an idea of findings that can be utilized. Used clothes that are no longer attractive can appear with a new face as seen in the example. Plain white shirts and sweaters that have been turned into decks with tie-dye technique become Sibori shirts or folding techniques and unique double-bounding patterned sweaters. Plain used clothes appear with new beutiful motifs and colors those invited to be re-worn.

The following is tie-dye, the result of exploration with the Pleat and Knot Techniques that have been carried out by students and lecturers, on new T-shirts and used shirts. Male and female service participants who prioritize personal creativity:

Tabel 3. Creative Exploration of Tie-Dye

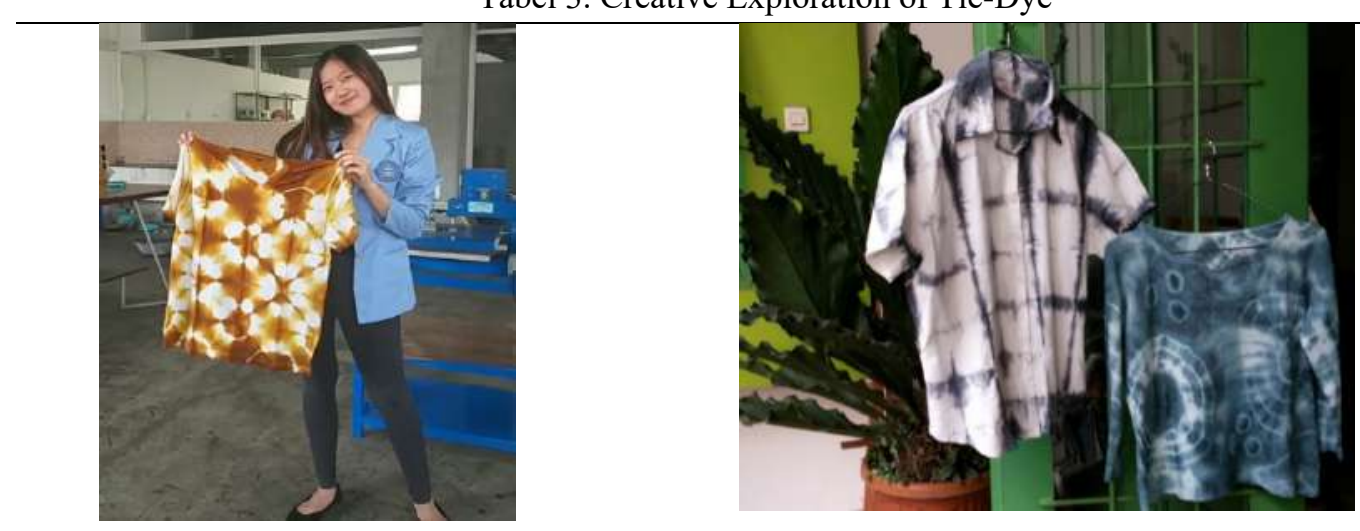

Tie-Dye Fold and Double Bounding Technique on Used Shirt and Sweater

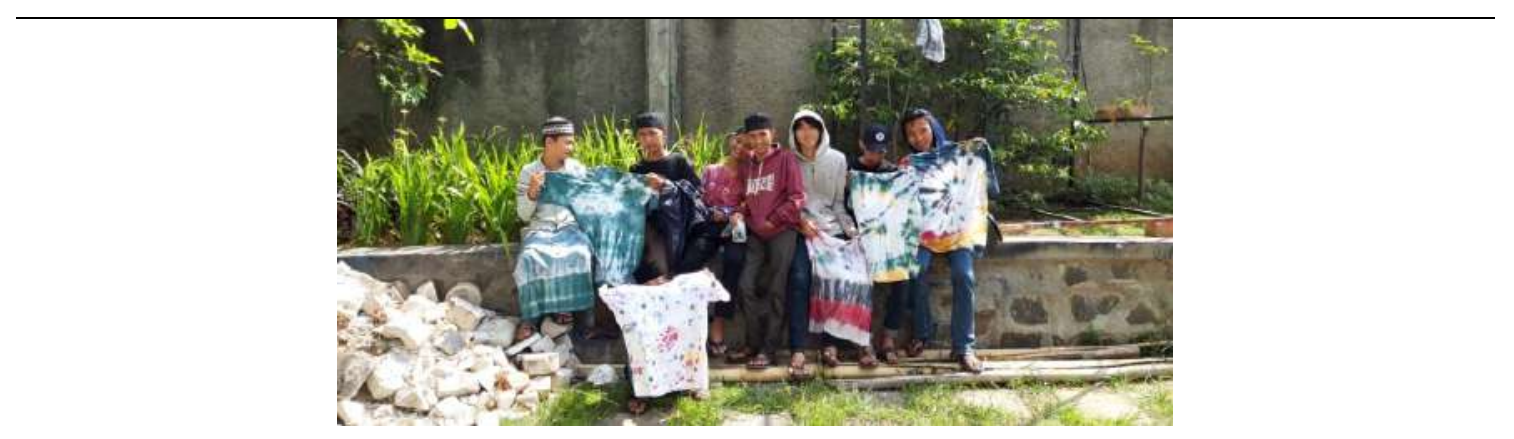

Tie-Dye T-shirt Exploration by Male Participant

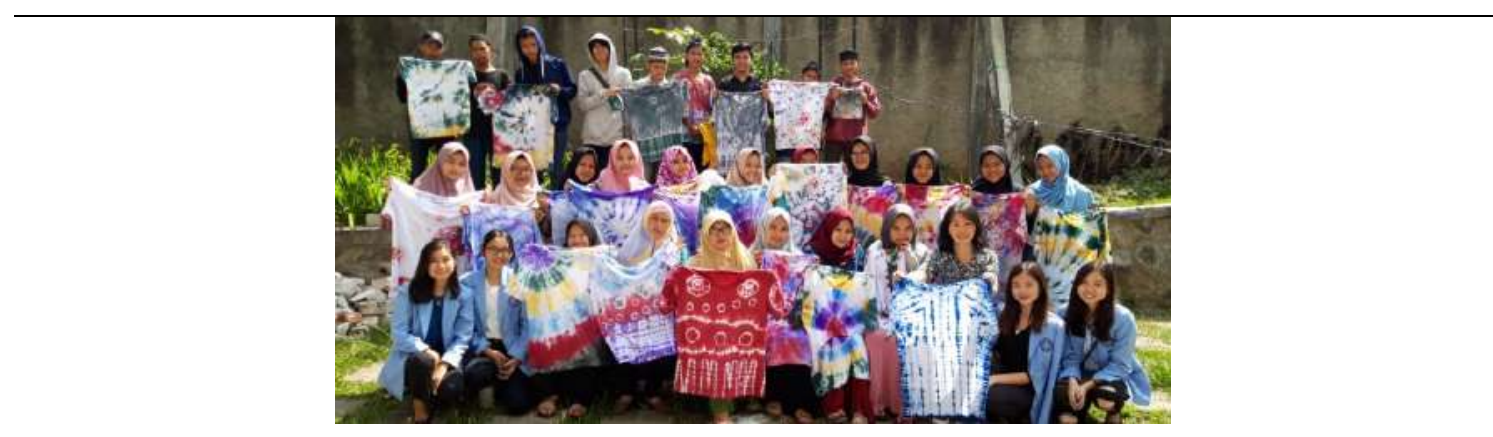

Tie-Dye T-shirt Exploration Results by Participants and Lecturer

(source: documentation of diploma III fashion design study program) 


\section{Conclusion}

This community empowerment activity has been carried out by the Diploma III Fashion Design Study Program, Faculty of Art and Design, Maranatha Christian University, with all heart for the purpose of increasing the passion of younger generation. The younger generation has wider opportunities to explore a variety of creativity that is useful for progress in the future. All areas of life require creativity to be able to develop to achieve better and more useful values. Without creativity, life will run statically, only repeating what has been there, no findings, no novelty, no spirit that gives happiness anymore. The development of tie-dye creations on T-shirts is a trigger for the younger generation to explore and find the creativity needed to stimulate creativity in different fields.

The participants had participated in this training enthusiastically completing each stage of the implementation of tie-dye method from beginning to the end happily. Participants feel proud of their unexpected and amazing creations, this was reflected in their body gestures when taking pictures together. The experience of exploring this unique and amazing tie-dye will open up insight, experience and knowledge that can provoke students to further develop themselves.

On the future encouraging students can make efforts to be self-sufficient so that in turn they are able to boost the family economy, further the regional economy. In the next community service activities will carry out the development of creativity in other forms, such as the use of used goods to support environmental friendly community empowerment programs.

\section{Acknowledgements}

Our gratitude goes to the participants, namely Islamic Boarding School students, Mr. Ahmad as Chair of RT 02 and Mrs. Siti Oliah as Secretary of RW 04 Sukawarna Village, Sukajadi District, who have given the opportunity to lecturers and students of Diploma III Fashion Design, Faculty of Art and Design to carry out community empowerment activity. This service activity is part of the task of lecturers in carrying out the Tri Dharma of Higher Education as an obligation that must be carried out. Without the participation of this community, the purpose of this community empowerment activity would not be possible. 


\section{References}

Adobe (2013). Hambatan Kreativitas Dalam Pendidikan: Pendidik dan Orang Tua Menilai Sistem. Adobe Publikasi, p. 32

Berman, S \& Korsten, P (2013). Memanfaatkan Kompleksitas: Wawasan Dari Chief Excecutive Officer Global Belajar, NY: IBM, p. 46

Majidah, Cahyaningsih, Saraswati, R.S., Inawati, W.A. (2021). Self-Identification of Homestay Management Problems and Canvas Busines Model, Journal of Innovation and Community Engagement (Journal of ICE), Vol 2, No.1, p.3

Munandar, Utami. (2004). Pengembangan Emosi Dan Kreatifitas. Jakarta: Rineka Cipta.

Widodo, Suryo Tri. (2013). Kriya Tekstil Tie-Dye Sebuah Media Eksplorasi Estetis Yang Populer Jurnal Seni Kriya Corak. Vol. 1 No. 2, November 2012-April https://journal.isi.ac.id/index.php/corak/article/view/2316 